\begin{tabular}{l} 
O P E R A T I O N S R E S E A R C H A N D D E C I S I O N S \\
\hline No. 2
\end{tabular}

DOI: $10.37190 /$ ord200204

\title{
INFORMATION GAP IN VALUE PROPOSITIONS OF BUSINESS MODELS OF LANGUAGE SCHOOLS
}

\author{
ZBIGNIEW MALARA, PAWEŁ ZIEMBICKI* \\ Faculty of Computer Science and Management, Wrocław University of Science and Technology, \\ ul. Łukasiewicza 5, 50-371 Wrocław, Poland
}

\begin{abstract}
The paper presents the results of the second stage of research on business models of language schools. It was assumed that there is a significant difference in the value propositions of schools and the expectations of their clients. An examination procedure was planned with the use of a questionnaire and statistical analysis such as factor analysis, on its basis. Respondents consisted of a group of school managers (representing the majority of enterprises in Lower Silesia) on the one hand and, on the other hand, a large group of former and current clients. The results of the research confirm the existence of a gap in the perception of the values of both groups. The analysis has been conducted in the convention of the business model canvas template. The distinctness of the offer's perception is presented in the form of activity packages, responsible for creating value for the clients (the right side of the model canvas). The structure of the packages, as a picture of the gap, is discussed. The results of the first stage of the research, diagnosing the influence of the surrounding elements on the business models of language schools, are also referred to. Directional changes in the business models that result from both stages of the research are suggested. The strategic dimension of the gap results from the strategy-business model relation. In light of the literature review, it may be supposed that the research is unique due to the segment of subjects and research methodology.
\end{abstract}

Keywords: enterprises segment, analysis (measurement), renewal, proposition, manager

\section{Introduction}

The paper presents the results of the diagnosis of the 2008 key component state of the Lower Silesian Voivodeship language schools business models, i.e., value propositions. The goal of this study is to identify key business model components currently used in language schools and to compare them with the model of their client expectation.

*Corresponding author, email address: pawel.ziembicki@pwr.edu.pl Received 8 May 2019, accepted 12 August 2020 
There are many studies related to client expectations in many different areas but, according to the authors' best knowledge, there are no such studies related to client expectations in the language school sector. Also, according to the authors, there are no studies related to language school business models and their key component identification. Based on the outcomes obtained from the diagnosis, it was assumed that the resulting situation allows one to identify the existence of a statistically significant gap between the value proposition of the offer of the language schools and the expectations of the clients in this respect. Due to the crucial importance of the value proposition in a business model, it is called an information gap in the segment. The concept of a gap is known in the analysis, strategic planning, and compared to a single entity and/or capital groups [25]. In consequence, diagnosing such a gap is linked to the problem of the strategic renewal of the enterprise [9]. Studies providing process framework for the renewal are known in strategic management literature [4]. Thus, comparing the strategic gap to a segment of language schools provides another cognitive aspect, and the conclusion from the diagnosis may be focused on indicating directional changes in the segment. This is the third stage of the research undertaken in the field of language school business models.

The issue of business models has been known in foreign and Polish literature for more than 20 years $[1,2]$. However, particular significance of the problem was demonstrated in the period when various propositions structuring business models, i.e., isolating their components and interrelations, creating different types of classifications and their properties, appeared on the publishing market [20,22]. The importance of business models has been clearly emphasised by practitioners and theoreticians of management to this day, e.g., $[5,12]$. The significance of business models described as a concept of a business model is relatively new and under constant development by business theoreticians and practitioners. The issue of business models is not sufficiently discussed in Polish literature. Its modern dimension is reflected in the fact that in the business practice, no one asks about plans but mainly about business models ${ }^{1}$. The Department of Management Infrastructure at the Faculty of Computer Science and Management of the Wrocław University of Science and Technology have been dealing with these issues for more than 10 years $[16,14,7]$. For 5 years, the research has been concerning business models of economic operators [17]. The following is one of the well-known definitions of a business model, fully conveying its sense and significance: a business model is logical interrelations between resources which are deployed by an organisation and activities which create value for broadly understood clients [15].

The part of the study presented in this paper (stage 2) refers to a specific market segment of enterprises in the education sector - language schools. This way, the conclusion about the business models used by language schools may have higher (different)

${ }^{1}$ From J. Niemczyk's review of the book by T. Falencikowski, Business model coherence. Concept and measurement, Wydawnictwo CeDeWu, Warsaw 2013 (in Polish). 
cognitive value than in the case of valuation of different entities, even if they refer to a selected sector (e.g., education). To maintain a standardised description and interpretation of the results, a specific business model template is assumed in the study. It uses a known template of Osterwalder and Pigneur [21], more precisely the value proposition and its right side consisting of four components: customer segments, interrelations, channels, and revenue structure. To establish the current state (and to diagnose the gap) it was necessary to obtain information from the majority of companies in the region and the clients of the schools. The sources of information were interviews and on-line platform questionnaires consisting of specific items referring to business models typical of language schools. This way, information from a large number of schools' clients was obtained. It was described in greater detail in the third part of the paper. It should be emphasised that the undertaken research fits in the empirical studies that have been conducted for several years by Polish researchers. Their works, focusing on specific assumptions and original business model templates, have their cognitive message. And so, e.g., Falencikowski presents the concept of business models measurement cohesion, understood as compliance of the components determining the creation of values (for the clients) with the components responsible for intercepting values (for the enterprise). In the empirical dimension, the proposition of measurement for several enterprises was examined (through interviews - management perception) [8]. Jabłoński, on the other hand, in analysing business models of enterprises from the New Connect market, assesses their innovativeness in terms of product/service and business model as a source of value of these companies. From among more than 200 enterprises, he presents a detailed description of 14 companies having favourable economic indicators from several years [11]. More sophisticated analysis is conducted by Jabłoński who deals with hybrids of business models and compares the empirical part with selected enterprises where he looks for answers to the context of hybridity [10].

The diagnosis of the gap is the second stage of research on the segment of language schools. In the first stage of the study, the same managers as in the second stage are asked questions about the impact of the external surrounding elements on the business model of their enterprise. The assessment of the effects was compared in two dimensions: significance, and favourability of the influence. It is a two-step approach, as it is crucial to eliminate insignificant surrounding elements. Once the significant elements are identified, it is important to assess their favourability to determine either the environment of language school business model is perceived either as an opportunity or as a threat for language schools business models. The conclusion from this analysis is compared with the listed above components of the business model, according to the approach of Osterwalder. A concise description of assumptions and results from the first stage and their full description is included in the paper [18]. The instrumental side of the paper (for determining the gap) are, on the one hand, surveys and interviews, and, on the other hand, a set of methods for statistical analysis and results translation on the business model template, to indicate activities (around those selected components of the 
model) to preferential rationalisation, according to the substantive essence of a strategic gap. Description of the instruments and interpretation of the research results constitute a fundamental part of the paper. Against this background, the present paper aims to demonstrate that the value offer (proposition) of language schools differs substantially from the expectations of the clients and that there is a possibility, with the use of the template of Osterwalder, to indicate directional modifications of components of the model which are a derivative of the research with the analysis of the influence of the surroundings (the first stage of the research). To emphasise the methodological specificity of the research in comparison with other studies, the concept of cohesion of a business model of Falencikowski is worth noting. The approach that is taken in the language schools' research could also be included in the cohesion category (value offers). However, in this case, it is the cohesion between real assessments of managers and clients, not only the managerial perception of what (business model components) generates value (for the client), and what contributes to intercepting value (for the enterprise).

\section{Description of the results obtained in the first stage of the study on business models}

As mentioned in the introduction, description of the conclusions formulated based on the analysis of external surroundings influence on language schools business model constitutes a background for the research on the information gap. The assessment of the influence of the surrounding elements of the schools was conducted by preparing a questionnaire and obtaining information from interviews and on-line method (Google Survey platform). The selected enterprises in the first stage later participated in the research on the information gap of the segment. These were enterprises which are in the category of small and medium-sized enterprises (SMEs). Generally, SMEs are characterised by high flexibility in market activities and adaptive skills to constantly changing conditions of the environment, and through stimulating innovative processes and modernisation have a positive effect on economic development. In 2016, non-financial business activity was conducted by 2013 enterprises in Poland. In SMEs, micro-enterprises, which constitute as much as $96.2 \%$ of the population are predominant, whereas small and medium-sized enterprises amount to $2.8 \%$ and $0.8 \%$, respectively ${ }^{2}$.

The reports analysing the language industry emphasise its dynamic and rapid changes. Over the years, since Poland's accession to the EU, changes in the educational services sector had an impact on the change in the assessment of the value of language

${ }^{2}$ Based on: Central Statistical Office, Activity of non-financial enterprises in 2017, https://stat. gov.pl/obszary-tematyczne/podmioty-gospodarcze-wyniki-finansowe/przedsiebiorstwa-niefinansowe/dzia lalnosc-przedsiebiorstw-niefinansowych-w-2016-r-,2,12.html?pdf=1 (accessed: 19.11.2018). 
competence in the EU. It should be emphasised as an important market factor, in the context of the surroundings of language schools and their business models that there is an existence of jobless growth. It is the cause of increased personalised competition in the labour market. It is an additional reason for which education and improving qualifications are becoming a prerequisite for survival for a growing number of collaborators of companies and institutions. According to the Register of Training Institutions (Rejestr Instytucji Szkoleniowych, RIS), at the end of 2018, this number amounted to 1596 entities in Poland and 146 in Lower Silesian Voivodeship. 96 language schools participated in the research which constitutes $2 / 3$ of all schools in the region. More than half of the enterprises (ca. 56\%) are persons who are performing sole proprietorship activity $^{3}$. The above background indicates that language companies are facing an evolutionary stage of changes, which transforms the segment (in two aspects: technology, and business model), whereby the range of transformations depends on the information gap in both aspects. The first of them, the hard part, lies outside the scope of the study, which, according to the components of the canvas template, is linked to resources, activities, and cost structure (left-hand side of the template). Naturally, relations between components translate into capacities and solutions included in its right-hand side. In the first stage of the research, concise information about the segment was obtained.

Agreed segment uniformity of language schools (initial, according to the canvas, component of the construction and modification of the business model) and a large sample of analysed enterprises from the SME category allowed one to conclude the state of the sector in Poland. Ultimately, for the research on environmental influences, based on a dozen or so literature items, 31 factors (elements $j=1,2, \ldots, 31$ ) representing further surroundings (21) and close, sectoral-competitive surroundings (10) were preselected. The essence of measuring the two dimensions of environment assessment, significance and favourability, were specified by providing an appropriate interpretation of expected perception of both dimensions. Using the Likert scale ( $1-5$ scale), the respondents spoke simultaneously about both contexts by describing 5 states: from insignificant to very significant and from very unfavourable to very favourable. The favourability dimension was used alternatively in the case of low significance. A random selection of enterprises from the sample was made with the use of the RIS database and the Central Statistical Office (CSO) database. Concentration in the perception of environmental influence on the right side of business models allowed assessing the stability of standards developed in segmentation of the clients, relations of cooperation with the clients, communication channels with them, and price sensitivity of enterprises behind the assumed value proposition. The enterprises participating in the first stage (and the second stage), according to the number of employed people, had the structure presented in Table 1.

${ }^{3}$ http://psz.praca.gov.pl/documents/10240/1012429/RIS\%20raport\%202013\%20PDF.pdf/b839706c03ee-46fe-a6fc-229a560512b3?t=1417694996000 (accessed: 24.12.2018). 
Table 1. Structure of the enterprises according to the number of employees, evaluating the impact of the surroundings on their business model components (stage 1)

\begin{tabular}{|l|c|c|}
\hline \multicolumn{1}{|c|}{ Number of employees } & Number of the companies & $\begin{array}{c}\text { Percentage } \\
{[\%]}\end{array}$ \\
\hline Micro-enterprise (1-10 employees) & 44 & 45.8 \\
\hline Small enterprise (11-50 employees) & 39 & 40.6 \\
\hline $\begin{array}{l}\text { Medium-sized enterprise } \\
\text { (51-250 employees) }\end{array}$ & 13 & 13.6 \\
\hline Total & 96 & \\
\hline
\end{tabular}

The reliability of the scale adopted in the research was assessed. The results confirmed its reliability with the use of Cronbach's Alpha (C-A) statistic concerning the significance and favourability of the surroundings ( 62 items, 31 for each dimension). The achieved result was positive, i.e., C-A coefficient amounted to 0.902 with the threshold value of more than 0.7 .

Table 2. Distribution of the results of the assessment of surrounding elements ( $s e_{i}-8$ cases) conforming to the requirement of the threshold of significance and favourability

(opportunities and threats) according to the average sectoral evaluation of these dimensions ( $S_{\text {avg }}, F_{\text {avg }}$ )

\begin{tabular}{|c|c|c|c|c|c|c|}
\hline \multicolumn{7}{|c|}{ Further surroundings - political-legal elements ( 0 cases) } \\
\hline \multirow{3}{*}{$\begin{array}{c}\text { Element } s e_{i}, \\
(i=1,2, \ldots, 22)\end{array}$} & & & Scale & & & \multirow{4}{*}{$\begin{array}{l}\text { Average } \\
\left(S_{\text {avg },} F_{\text {avg }}\right)\end{array}$} \\
\hline & 1 & 2 & 3 & 4 & 5 & \\
\hline & \multicolumn{5}{|c|}{ Number of assessments $\left(S_{i}, F_{i}\right)$} & \\
\hline \multirow{2}{*}{\multicolumn{7}{|c|}{ Further surroundings - economic elements ( 4 cases) }} \\
\hline & & & & & & \\
\hline Foreign investments level $\left(\mathrm{se}_{4}\right)$ & $(0,0)$ & $(0,1)$ & $(35,35)$ & $(25,23)$ & $(36,37)$ & $(4.01,4.00)$ \\
\hline Economic growth $\left(\mathrm{se}_{6}\right)$ & $(0,8)$ & $(0,7)$ & $(29,7)$ & $(22,25)$ & $(45,49)$ & $(4.17,4.04)$ \\
\hline Internationalisation of the Polish economy $\left(\mathrm{se}_{7}\right)$ & $(0,8)$ & $(0,6)$ & $(19,8)$ & $(34,21)$ & $(43,53)$ & $(4.25,4.09)$ \\
\hline Seasonality of demand (ses) & $(0,53)$ & $(0,34)$ & $(14,9)$ & $(36,0)$ & $(46,0)$ & $(4.33,1.54)$ \\
\hline \multicolumn{7}{|c|}{ Further surroundings - demographic and socio-cultural elements ( 0 cases $)$} \\
\hline \multicolumn{7}{|c|}{ Further surroundings - technological elements $(0$ cases $)$} \\
\hline \multicolumn{7}{|c|}{ Further surroundings - international elements ( 1 case) } \\
\hline Integration with the European Union $\left(s e_{12}\right)$ & $(0,0)$ & $(0,5)$ & $(33,20)$ & $(19,39)$ & $(44,32)$ & $(4.11,4.02)$ \\
\hline \multicolumn{7}{|c|}{ Immediate surroundings - competitive-sectoral elements ( 3 cases) } \\
\hline Bargaining power of the recipients $\left(s e_{15}\right)$ & $(0,35)$ & $(2,36)$ & $(29,18)$ & $(23,6)$ & $(42,1)$ & $(4.09,1.98)$ \\
\hline Risks posed by the substitutes $\left(s e_{16}\right)$ & $(0,36)$ & $(1,34)$ & $(14,24)$ & $(36,3)$ & $(4,0)$ & $(4.30,1.95)$ \\
\hline Intensification of competition in the sector $\left(s e_{17}\right)$ & $(0,27)$ & $(1,45)$ & $(21,19)$ & $(29,4)$ & $(45,1)$ & $(4.23,2.03)$ \\
\hline
\end{tabular}

The analysis of the impact was based on stipulated thresholds for both dimensions (in the context of 1-5 scale). For the significance of a given element, it was the threshold of 3.0. In the case of the other dimension - favourability - two thresholds were introduced: the first one was 2.5 (1-2.5 - favourability class: threat), and the second one was 3.5 (range $3.5-5$ - favourability class: opportunities). These elements $\left(s e_{i}\right)$, which fit 
into the ranges were classified as having considerable potential to influence business models of language schools, with significance, exceeding the threshold and being within the range of stipulated opportunities and threats according to the dimension of favourability. The results of this selection have been presented in Table 2. Full description of the 22 cases was included in the first part of the research [18].

The obtained results allow one to outline the influence of these eight elements $\left(\mathrm{se}_{4}, \mathrm{se}_{6}\right.$, $\left.s e_{7}, s e_{8}, s e_{12}, s e_{15}, s e_{16}, s e_{17}\right)$ on the components of the business model of language schools (four on the right-hand side of the canvas template) and the value proposition. It is characterised by subjectivity resulting from the interpretation of the authors (Fig. 1).

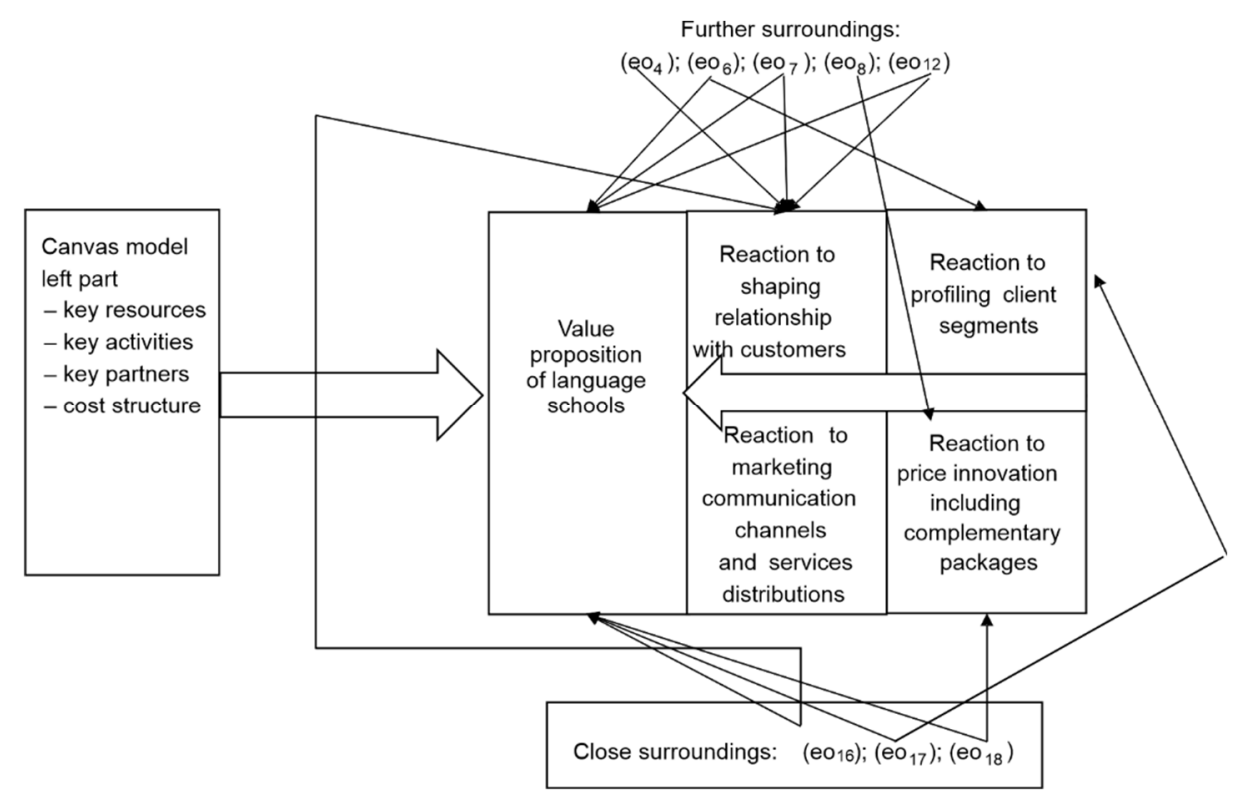

Fig. 1. Selected surrounding elements having a threshold valuation of significance and favourability and their influence (narrow arrows) on the components on the business model of language schools in the region

The presented suggestions about the influence of selected elements on the components of the business model were used as a background for the analysis conducted in the second stage of the study.

\section{Results and interpretation of the second stage of the research on business models}

The same language schools (96) and a large group of clients (337 former, current and potential) of the language schools from Lower Silesian Voivodeship participated at 
this stage. The prepared questionnaire included, according to the Likert scale (1-5), references to all five components of a business model. Its preparation required considerable diagnostic effort to reflect the current specific functioning and to fit into the convention of the business model canvas template. The work on the preparation took place in the period from March 2018 to October 2018. The study was conducted in the period from October 2018 to December 2018.

The survey included the possibility of choosing the appropriate segment of clients and, based on the previous selection, answers to questions about the right-hand side of the canvas template and contextual information, e.g., company's age, key manager's gender, location, etc. Extracting data from the questionnaires from companies and clients, in the process of statistical processing and following the steps of research conduct [6], allowed verifying a series of hypotheses determining the state and allowed to formulate the conclusions included in the objective of the second stage provided in the introduction to the paper. The study below contains the most important results, all assumptions and partial results, while conclusions are included in [27].

\subsection{Methodological guidelines and inference tools}

The questionnaire used in the research referred to the same components of business models for the group of companies (96) as to the group of clients (337 people) of language schools. It contained, apart from the option profile, 18 activities which may be classified into two components of the model canvas: relations with the clients, and communication and distribution channels. The component of revenue structure was represented by the type of foreign languages (11) and the evaluation of services referring to those languages (11) in five price ranges. The enterprises studied - language schools in Lower Silesia - use two convenient (simple) techniques in price-fixing. The first one is the rule of cost plus - a mark-up on costs, which may contribute to a certain price cartel in a situation when other competitors also use this technique. The second one is imitating the competition [26]. Both techniques cause price manoeuvres and tactics to limit the capability of managing them [23]. The fourth component of the business model - client segments - was included in the questionnaire in six categories of courses for the clients (a course for individual clients, a course for preschool groups, a course for school groups, a course for university students, a course for groups of adults, a course for enterprises). In a standard way, the profile of value propositions was formulated by introducing a mosaic of languages, levels of education and 6-course forms (vacation, one semester, two semesters, certificated, intensive, private). For analysis of the results of the studies, only important answers from the respondents (SMEs of the language services sector and their clients) were used. Answers omitted by the respondents were not analysed as they were considered irrelevant. In the past, the adopted convention of interviews and survey templates (for SMEs) stressed the assessment of phenomena and 
processes in the long term. The answers were encoded with the use of the number in the following way: 1 - ineffective, with no impact, insignificant or very unfavourable, 2 - not very effective, with little impact, not very significant or unfavourable, 3 - moderately effective, with moderate impact, moderately significant or moderately favourable, 4 - effective, having an impact, significant or favourable, 5 - very effective, with great impact, very significant or very favourable.

Statistical verification included the following analytical situations. Reliability and accuracy of the scales of measurement were indicated separately for entrepreneurs and target recipients. In the case of the first one, a standard indicator was used - Cronbach's Alpha statistic with the threshold value of 0.7. To determine the accuracy, the method of expert assessment was used. After consulting business theorists and practitioners ${ }^{4}$, a simple analysis of answer frequency was performed to find a situation in which the average exceeded the threshold of 4.0. An analysis of data distribution was also conducted: histograms and quartile-quartile diagrams were prepared, conclusions from the visual assessment were drawn, and then assessment of symmetric measures (obliquity, kurtosis and their standard errors) were made concerning a normal distribution. It was also necessary to use the Kolmogorov-Smirnov test with the Lilliefors modification (K-S-L) and the Shapiro-Wilk test (S-W) for the majority of the scales (the S-W test for samples smaller than 50 and the K-S-L test for samples bigger than 50 and smaller than 100). The analysis of interrelations and structures of the factors was performed with the use of factor analysis. The analysis was focused on determining the key components of currently used SME business models in the language services sector and the expected value proposition by their current and/or potential clients. The stages of the proceedings referred to establishing the number of factors, selecting the type of factor rotation, and factor interpretation [3]. Before these stages, the probability of standard deviations and variance for individual variables, shaping of the coefficient of the Kaiser -Meyer-Olkin (K-M-O) measure of sampling adequacy with the threshold of 0.5 , were checked and the hypothesis on whether the empirical matrix includes zero correlation coefficients examined with the use of Bartlett's test. These estimations allowed determining the above-mentioned number of factors with the use of Kaiser method. After establishing the number of factors, the questions creating individual factors were identified. The direct Oblimin oblique rotation method with the Kaiser normalisation was used for this purpose, allowing determination of correlating factors in assessing the power of loading of the factors. In the next step, the assessment of the correlation between isolated factors for all analysed scales was performed. After finding the questions which create factors, individual factors were given conventional names. The convention

\footnotetext{
${ }^{4}$ These were, on the one hand, the participants of an academic seminar, and, on the other hand, the managers of several language schools in Lower Silesia who participated in the research a couple of years earlier.
} 
adopted in the description was the word package, symbolising the possibility (non-excludability) of mixing very detailed and specific marketing efforts. The isolated packages (for each group of target recipients) constitute the essence of research conduct. They are also the basis for the interpretation of directional modifications of business models in the language school segment.

\subsection{Selected results and their interpretation}

Assumptions, scope, and methods used in the second stage of the research and presented in 2.1 demonstrate the way of coming to conclusions about the strategic gap in the language school segment. Apart from this direction, the obtained information allows one to conduct a series of contextual analyses illustrating the specific nature of companies from this segment. Focusing on the aim of the work, the assessment of the gap between the value offer of the language schools and the expectations of their clients in terms of value propositions determines the requirements of presentation of the results of this work. The results which document the definitive findings are presented below. It should be noted that the statistical processing has repetitive nature due to dividing the recipients into 6 groups listed above. For each of them, the analyses and partial assessments result from information from the enterprises for which scales 1.1 to 1.6 are used and from the clients for which scales 2.1 to 2.6 are used. Table 3 shows the data related to the descriptive statistics analysis for the clients (scale 2.1-2.6) and the language schools (1.1-1.6)

Table 3. Descriptive statistics of the scales

\begin{tabular}{|l|c|c|c|c|c|c|}
\hline Scale & 2.1 & 2.2 & 2.3 & 2.4 & 2.5 & 2.6 \\
\hline Valid answers & 53 & 48 & 69 & 78 & 56 & 33 \\
\hline Data deficit & 0 & 0 & 0 & 0 & 0 & 0 \\
\hline Average & 3.24 & 2.99 & 3.13 & 3.31 & 3.08 & 3.16 \\
\hline Median & 3.32 & 3.00 & 3.16 & 3.42 & 3.08 & 3.37 \\
\hline Mode & 3.68 & 3.11 & 3.68 & 3.53 & 2.95 & 3.63 \\
\hline Standard deviation & 0.464 & 0.357 & 0.596 & 0.484 & 0.350 & 0.522 \\
\hline Range & 1.95 & 1.58 & 2.05 & 2.05 & 1.42 & 1.68 \\
\hline Scale & 1.1 & 1.2 & 1.3 & 1.4 & 1.5 & 1.6 \\
\hline Valid answers & 43 & 30 & 47 & 46 & 41 & 39 \\
\hline Data deficit & 0 & 0 & 0 & 0 & 0 & 0 \\
\hline Average & 2.94 & 2.78 & 2.82 & 2.92 & 3.02 & 2.66 \\
\hline Median & 2.86 & 2.73 & 2.80 & 2.89 & 3 & 2.53 \\
\hline Mode & 2.37 & 2.37 & 2.04 & 2.58 & 3.67 & 1.78 \\
\hline Standard deviation & 0.515 & 0.371 & 0.534 & 0.466 & 0.531 & 0.563 \\
\hline Range & 1.94 & 1.29 & 1.73 & 1.63 & 1.93 & 2.02 \\
\hline
\end{tabular}

Table 4 presents the results of using the Kolmogorov-Smirnov test with the Lilliefors modification (K-S-L) and the Shapiro-Wilk test (S-W). 
Table 4. Kolmogorov-Smirnov test (K-S-L) and Shapiro-Wilk test (S-W) for selected scales

\begin{tabular}{|c|c|c|c|c|c|c|}
\hline \multirow{2}{*}{ Scale } & \multicolumn{3}{|c|}{ Kolmogorov-Smirnov test } & \multicolumn{3}{c|}{ Shapiro-Wilk test } \\
\cline { 2 - 7 } & Statistic & $\begin{array}{c}\text { Degrees } \\
\text { of freedom }(d f)\end{array}$ & Significance $(p)$ & Statistic & $\begin{array}{c}\text { Degrees } \\
\text { of freedom }(d f)\end{array}$ & Significance $(p)$ \\
\hline 1.1 & 0.137 & 43 & 0.041 & 0.950 & 43 & 0.058 \\
\hline 1.2 & 0.126 & 30 & 0.200 & 0.943 & 30 & 0.110 \\
\hline 1.3 & 0.156 & 47 & 0.006 & 0.928 & 47 & 0.006 \\
\hline 1.4 & 0.106 & 46 & 0.200 & 0.953 & 46 & 0.062 \\
\hline 1.5 & 0.103 & 41 & 0.200 & 0.956 & 41 & 0.111 \\
\hline 1.6 & 0.103 & 39 & 0.200 & 0.957 & 39 & 0.140 \\
\hline 2.1 & 0.102 & 53 & 0.200 & 0.965 & 53 & 0.123 \\
\hline 2.2 & 0.085 & 48 & 0.200 & 0.985 & 48 & 0.802 \\
\hline 2.3 & 0.174 & 69 & 0.000 & 0.918 & 69 & 0.000 \\
\hline 2.4 & 0.151 & 78 & 0.000 & 0.925 & 78 & 0.000 \\
\hline 2.5 & 0.109 & 56 & 0.092 & 0.977 & 56 & 0.349 \\
\hline 2.6 & 0.183 & 33 & 0.007 & 0.896 & 33 & 0.004 \\
\hline
\end{tabular}

From the factor analysis in further steps, the basis for establishing the number of factors for the given scales was obtained based on percentage of the explained variance. It is presented in Table 5 .

Table 5. Numbers of isolated factors for scales 1.1-1.6 and 2.1-2.6

\begin{tabular}{|l|c|c|c|c|c|c|c|c|c|c|c|c|}
\hline Scale & 1.1 & 1.2 & 1.3 & 1.4 & 1.5 & 1.6 & 2.1 & 2.2 & 2.3 & 2.4 & 2.5 & 2.6 \\
\hline No. of factors & 4 & 5 & 5 & 5 & 5 & 5 & 6 & 5 & 4 & 5 & 5 & 4 \\
\hline $\begin{array}{l}\text { Explained } \\
\text { variance [\%] }\end{array}$ & 55.49 & 55.89 & 59.13 & 59.91 & 66.02 & 67.86 & 67.69 & 68.50 & 67.89 & 65.45 & 56.57 & 78.15 \\
\hline
\end{tabular}

In the last step, after establishing the number of factors for each scale, questions which create particular factors were selected from the questionnaire (referring to the activities of language schools, which create components of the business model canvas). It was done, as it was mentioned, with the use of the method of oblique rotation - the direct Oblimin with the Kaiser normalisation ${ }^{5}$. Table 6 presents the example of the rotation matrix of four factors through the activities of language schools for the first scale 1.1. An identical analysis was performed for other scales.

The text in bold indicates activities (questions) creating the given factor, according to the threshold of over 0.5 (or below -0.5) [24]. Factor correlation for all scales was also analysed. In a few situations (three) it exceeds the value of 0.5 . The information about the activities of language schools, on the one hand, according to the managers (scale 1.1-1.6), and, on the other hand, according to the clients (2.1-2.6) for the defined

\footnotetext{
${ }^{5}$ In practice, situations in which factors are not even remotely interdependent are extremely rare.
} 
target groups was obtained in a way to allow to picture the difference in the perceived value offer.

Table 6. Rotation activities of four factors for scale 1.1

\begin{tabular}{|l|c|c|c|c|}
\hline \multicolumn{1}{|c|}{ Language schools' activities } & 1 & 2 & 3 & 4 \\
\hline Free educational materials & 0.944 & -0.177 & 0.279 & -0.182 \\
\hline Tailor-made offer & 0.913 & -0.231 & 0.363 & 0.018 \\
\hline Free classes & 0.915 & -0.141 & 0.187 & -0.020 \\
\hline Discount for a certificate & 0.898 & -0.155 & 0.204 & -0.022 \\
\hline Loyalty program & 0.847 & -0.250 & 0.348 & 0.031 \\
\hline Free conversations & 0.841 & -0.022 & 0.375 & -0.206 \\
\hline Promotions and discounts & 0.645 & 0.085 & 0.073 & -0.359 \\
\hline Dedicated customer service consultant & 0.532 & -0.205 & 0.170 & 0.178 \\
\hline Word of mouth advertising & 0.209 & -0.928 & -0.031 & -0.003 \\
\hline Online contact form & 0.052 & 0.727 & 0.164 & 0.387 \\
\hline Advertising in social media & -0.093 & 0.659 & -0.039 & 0.113 \\
\hline Internet advertising & -0.369 & 0.634 & 0.221 & 0.186 \\
\hline Leaflets and billboards & 0.035 & 0.035 & 0.673 & -0.108 \\
\hline Telephone contact & 0.275 & 0.010 & 0.383 & -0.039 \\
\hline Individual contact & 0.068 & -0.043 & 0.375 & -0.330 \\
\hline Online consultation & 0.300 & 0.238 & 0.330 & -0.330 \\
\hline Price range of the services & 0.321 & -0.231 & 0.189 & $\mathbf{- 0 . 5 1 5}$ \\
\hline Radio advertising & 0.307 & -0.049 & 0.198 & 0.363 \\
\hline
\end{tabular}

\subsection{Assessment of the information gap of the segment}

As based on the obtained results, (visible) differences may be observed from two perspectives: language schools (manager projection), and their clients. To facilitate assessment and concise overview of the status quo, the term activity package was introduced. Thus, the term was used in the analysis to emphasise the examined information gap of value propositions. Table 7 presents the case of scales 1.1 and 2.1 (individual courses - assessments of schools and, adequately, expectations of the clients).

Table 7. Package of activities as a result of the statistical analysis for individual courses as the offer of the schools (1.1) and the expectations of the clients (2.1)

\begin{tabular}{|c|c|c|c|}
\hline \multicolumn{2}{|c|}{$\begin{array}{c}\text { Scale } 1.1 \\
- \text { individual courses (language schools) }\end{array}$} & \multicolumn{2}{|c|}{$\begin{array}{c}\text { Scale } 2.1 \\
\text { - individual courses (clients) }\end{array}$} \\
\hline Factor & $\begin{array}{c}\text { Activities } \\
\text { creating the factor }\end{array}$ & Factor & $\begin{array}{c}\text { Activities } \\
\text { creating the factor }\end{array}$ \\
\hline $\begin{array}{l}\text { Personalised offer } \\
\text { package based on } \\
\text { standard promotion } \\
\text { efforts }\end{array}$ & $\begin{array}{l}\text { free educational materials, } \\
\text { tailor-made offer, free classes, } \\
\text { discount for a certificate, } \\
\text { loyalty program }\end{array}$ & $\begin{array}{l}\text { sample incentive } \\
\text { package supported } \\
\text { with word of mouth } \\
\text { techniques }\end{array}$ & $\begin{array}{l}\text { free conversations, } \\
\text { word of mouth advertising, } \\
\text { free classes }\end{array}$ \\
\hline
\end{tabular}


Table 7. Package of activities as a result of the statistical analysis for individual courses as the offer of the schools (1.1) and the expectations of the clients (2.1)

\begin{tabular}{|c|c|c|c|}
\hline \multicolumn{2}{|c|}{$\begin{array}{c}\text { Scale } 1.1 \\
\text { - individual courses (language schools) }\end{array}$} & \multicolumn{2}{|c|}{$\begin{array}{c}\text { Scale } 2.1 \\
\text { - individual courses (clients) }\end{array}$} \\
\hline & $\begin{array}{l}\text { free conversations, } \\
\text { promotions and discounts, } \\
\text { dedicated customer } \\
\text { service consultant }\end{array}$ & & \\
\hline $\begin{array}{l}\text { Internet activity } \\
\text { package supported } \\
\text { with word of mouth } \\
\text { techniques }\end{array}$ & $\begin{array}{l}\text { word of mouth advertising, } \\
\text { online contact form, } \\
\text { advertising in social media, } \\
\text { Internet advertising }\end{array}$ & $\begin{array}{l}\text { Internet activity } \\
\text { package }\end{array}$ & $\begin{array}{l}\text { online contact form, Internet } \\
\text { advertising, advertising } \\
\text { in social media }\end{array}$ \\
\hline $\begin{array}{l}\text { Traditional } \\
\text { advertising package }\end{array}$ & leaflets and billboards & \begin{tabular}{|l|} 
sales promotion \\
package supported with \\
pro-loyalty incentives
\end{tabular} & $\begin{array}{l}\text { loyalty program, promotions } \\
\text { and discounts }\end{array}$ \\
\hline \multirow[t]{3}{*}{$\begin{array}{l}\text { Pricing } \\
\text { techniques package }\end{array}$} & price range of the services & $\begin{array}{l}\text { pricing techniques } \\
\text { package }\end{array}$ & price range of the services \\
\hline & & \begin{tabular}{|l|} 
personalised \\
communication \\
package supported with \\
traditional advertising \\
\end{tabular} & $\begin{array}{l}\text { tailor-made offer, discount for } \\
\text { a certificate, free educational } \\
\text { materials, online consultation }\end{array}$ \\
\hline & & \begin{tabular}{|l|} 
personalised offer \\
package with \\
operational bonuses
\end{tabular} & $\begin{array}{l}\text { individual contact, radio } \\
\text { advertising, telephone contact }\end{array}$ \\
\hline
\end{tabular}

Comparison of the set of packages for individual courses demonstrates the gap in the perception of value proposition preferences by language schools and target recipients. Similar comparisons can be performed for the remaining scales. The differences are noticeable. Table 8 shows a full set of identified packages based on the achieved results.

Table 8 indicates the differences in assessment, expressed by the language school managers and the expectations of the clients. The packages were placed in the table in such a way so as to link similar situations. The list of assessed activities (actions) is limited to 18 items, because, on the one hand, the spectrum of differences was narrowed down, and, on the other hand, the differences occurring in such situation reinforced the belief in the existence of the information gap in the language schools segment.

The diagnosed situation in the language school segment (gap) should be referred to the results of the first stage, i.e., the impact of surrounding elements on business models. The indicated impact on the components of business models (Fig. 1) is of ancillary nature and may be more accurately used in more in-depth studies targeting packages the content of which is mostly an integrated collection of activities. However, such element as, for instance, seasonality $\left(\mathrm{se}_{8}\right)$ and its influence on a component of language school revenue, including price context (Fig. 1), may translate into packages (Table 8) in which the price context occurs. 
Table 8. Packages of activities offered by the language schools expected by the target recipients for all 6 isolated scales (initial segmentation)

\begin{tabular}{|c|c|c|c|}
\hline Group & $\begin{array}{c}\text { Activity package } \\
\text { of the language schools }\end{array}$ & Group & $\begin{array}{c}\text { Activity package } \\
\text { expected by the clients }\end{array}$ \\
\hline \multirow{6}{*}{1.1} & $\begin{array}{l}\text { personalised offer package based } \\
\text { on standard promotion efforts }\end{array}$ & \multirow{6}{*}{2.1} & $\begin{array}{l}\text { sample incentive package } \\
\text { supported with word of mouth techniques }\end{array}$ \\
\hline & $\begin{array}{l}\text { Internet activity package supported with } \\
\text { word of mouth techniques }\end{array}$ & & Internet activity package \\
\hline & traditional advertising package & & $\begin{array}{l}\text { sales promotion package supported with } \\
\text { pro-loyalty incentives }\end{array}$ \\
\hline & pricing techniques package & & pricing techniques package \\
\hline & & & $\begin{array}{l}\text { personalised communication package } \\
\text { supported with traditional advertising }\end{array}$ \\
\hline & & & $\begin{array}{l}\text { personalised offer package } \\
\text { with operational bonuses }\end{array}$ \\
\hline \multirow{5}{*}{1.2} & $\begin{array}{l}\text { traditional advertising package } \\
\text { supported with sample incentives }\end{array}$ & \multirow{5}{*}{2.2} & $\begin{array}{l}\text { developed communication package supported } \\
\text { with certificates of effects and professionalism }\end{array}$ \\
\hline & $\begin{array}{l}\text { sales promotion package supported } \\
\text { with word of mouth techniques }\end{array}$ & & personalised offer package \\
\hline & $\begin{array}{l}\text { Internet activity package supported } \\
\text { with personalised context }\end{array}$ & & $\begin{array}{l}\text { Internet activity package supported } \\
\text { with focus incentives }\end{array}$ \\
\hline & $\begin{array}{l}\text { traditional incentives package supported } \\
\text { with pro-loyalty effects }\end{array}$ & & traditional and internet contact package \\
\hline & $\begin{array}{l}\text { personalised communication package } \\
\text { supported with pricing techniques }\end{array}$ & & pricing techniques package \\
\hline \multirow{5}{*}{1.3} & $\begin{array}{l}\text { personalised communication package } \\
\text { supported with focus incentives }\end{array}$ & \multirow{5}{*}{2.3} & $\begin{array}{l}\text { unconventional advertising package } \\
\text { supported with direct impact }\end{array}$ \\
\hline & $\begin{array}{l}\text { price incentives package supported } \\
\text { with broad advertising }\end{array}$ & & $\begin{array}{l}\text { pricing techniques package supported } \\
\text { with focus incentives }\end{array}$ \\
\hline & \begin{tabular}{|l} 
shaping relationships package \\
supported with pro-loyalty incentives
\end{tabular} & & \begin{tabular}{|l} 
sales promotion package supported \\
with pro-loyalty incentives
\end{tabular} \\
\hline & $\begin{array}{l}\text { internet advertising package supported } \\
\text { with sample incentives }\end{array}$ & & sample incentives package \\
\hline & \begin{tabular}{|l|} 
traditional advertising package supported \\
with personalised communication
\end{tabular} & & \\
\hline \multirow{5}{*}{1.4} & $\begin{array}{l}\text { pricing techniques package supported } \\
\text { with traditional advertising }\end{array}$ & \multirow{5}{*}{2.4} & $\begin{array}{l}\text { sample incentives package supported } \\
\text { with pro-loyalty incentives } \\
\text { and word of mouth techniques }\end{array}$ \\
\hline & traditional advertising package & & $\begin{array}{l}\text { traditional advertising package supported } \\
\text { with demonstration techniques }\end{array}$ \\
\hline & $\begin{array}{l}\text { Internet activity package supported } \\
\text { with personalised offer }\end{array}$ & & Internet activity package \\
\hline & $\begin{array}{l}\text { direct communication package supported } \\
\text { with sample incentives }\end{array}$ & & direct consultation package \\
\hline & $\begin{array}{l}\text { personalised communication package } \\
\text { supported with focus incentives }\end{array}$ & & incentives package through direct contact \\
\hline
\end{tabular}


Table 8. Packages of activities offered by the language schools expected by the target recipients for all 6 isolated scales (initial segmentation)

\begin{tabular}{|c|c|c|c|}
\hline \multirow{5}{*}{1.5} & $\begin{array}{l}\text { personalised communication package } \\
\text { supported with traditional } \\
\text { and word of mouth advertising }\end{array}$ & \multirow{5}{*}{2.5} & personalised communication package \\
\hline & $\begin{array}{l}\text { Internet activity package supported } \\
\text { with personalised offer }\end{array}$ & & Internet activity package \\
\hline & $\begin{array}{l}\text { pro-loyalty incentives package } \\
\text { supported with sample incentives }\end{array}$ & & $\begin{array}{l}\text { sample incentives package } \\
\text { supported with personalised contact }\end{array}$ \\
\hline & pricing techniques package & & $\begin{array}{l}\text { pricing techniques package } \\
\text { supported with personalised offer }\end{array}$ \\
\hline & $\begin{array}{l}\text { sales promotion package supported } \\
\text { with sample incentives }\end{array}$ & & traditional advertising package \\
\hline \multirow{5}{*}{1.6} & $\begin{array}{l}\text { personalised offer package supported with tra- } \\
\text { ditional advertising }\end{array}$ & \multirow{5}{*}{2.6} & $\begin{array}{l}\text { personalised offer package supported } \\
\text { with traditional advertising }\end{array}$ \\
\hline & \begin{tabular}{|l|} 
Internet activity package supported \\
with personalised communication
\end{tabular} & & Internet activity package \\
\hline & $\begin{array}{l}\text { pricing techniques package supported with } \\
\text { sample incentives }\end{array}$ & & Pricing techniques package \\
\hline & word of mouth techniques advertising package & & $\begin{array}{l}\text { sample incentives package supported } \\
\text { with personalised contact } \\
\text { and word of mouth techniques }\end{array}$ \\
\hline & $\begin{array}{l}\text { sample incentives package supported } \\
\text { with pro-loyalty incentives }\end{array}$ & & \\
\hline
\end{tabular}

\section{Conclusions}

The research conducted in the second stage referred to the demonstration the gap between the value offer (proposition) of the language schools and the expectations of the clients confirmed the significant difference, despite the fact that a limited number of activities were available. They were formulated in the convention of the business model canvas template, with limitation only to the right-hand side of the model, which is responsible for delivering value from the customer. Due to that, in the next step, it was possible to assess the direction of changes in the business model of language schools, the source of which was determined in the information gap. The imposed analytical approach - reformulated into the survey questions - defined by six groups of target recipients, despite the fact that the standardised division according to the type of courses may be in the form of modification and proposition of the business model. In line with the principle of creating models, the construction of the models may initially involve developing so-called model template which provides guidelines for specific arrangements [20]. 
It seems that enterprises are unaware of the advantages of social media and internet communication channels (indicated for all segments). Most enterprises blindly use them because they are popular, but they do not realize that it is a very powerful tool which can be used to strengthen business models. Enterprises use sample incentives, but only as strengthening for the main package, however, customers express that for it is even more important - indicated as one of the main packages for 4 segments. Surprisingly, customers indicated personalised offer package for the preschool group course. It can be presumed that clients expect more flexibility in terms of schedules and learning programs and materials adjustments to preschool groups level. The authors suppose that the enterprises' flexibility is very limited and language schools standardise their offer base too much.

In the event of keeping the above-mentioned division of courses (target recipients), it becomes natural to indicate the division template, in which, within a single organism (enterprise), the development cycle (modification) of the components of the business model is created separately for each of the identified client segments. Naturally, the possibility of using the resources, key measures, channels and relations for focus value offer is taken advantage of in the first place. This separation (client segment) may necessarily differentiate between specific arrangements, which often takes place within a single organisation and/or with the participation of business partners. In certain situations, it leads to isolating separate entities (units). The SME language schools are unlikely to be confronted with this separation. The indicated background for changes in the business model (with keeping the segments) is one of the possible ways of the business model renewal. In the event of going beyond the standard arrangement, it is necessary to professionally examine the clients to see their profile differences and their expected preferences. An example of such an approach is, among others, the proposition of so-called tasks to perform by the clients [13] or the recommendations stemming from the model lean canvas [19].

The issue described as the renewal of business models is connected with the concept of strategic renewal mentioned before. This connection is a direct result of the relation between the business model and the strategy. Either the business model is considered as the element of the strategy or a separate construct defining the strategy [8]. The strategy renewal (in terms of the business model renewal) requires identifying and diagnostic actions, making changes (e.g., in aims), which further translates into changing the processes and actions [4].

\section{References}

[1] Aмiт R., Zотт C., Value creation in e-business, Strat. Manage. J., 2001, 22 (6-7), 493-520.

[2] BANASZYK P., Business model as a basis of strategic management of the enterprise, Zeszyty Naukowe Akademii Ekonomicznej w Poznaniu, 2004, 43, 7-27 (in Polish). 
[3] BEDYŃSKA S., CYPRYAŃSKA M., Advanced methods of creating indicators - exploratory factor analysis and testing of scale reliability, [In:] S. Bedyńska, S. Cypryańska (Eds.), Statistical guidepost 1. A practical introduction for statistical inference, Wydawnictwo Naukowe Sedno, Warsaw 2013, 243 -256 (in Polish).

[4] BeŁz G., Cyfert S., Strategic and organizational renewal of enterprise, Wydawnictwo Uniwerystetu Ekonomicznego we Wrocławiu, Wrocław 2017 (in Polish).

[5] Bock A., GeOrg G., The business model book: design, build and adapt business ideas that thrive, Pearson Education Limited, 2017.

[6] CZAKON W., Basics of research methodology in management sciences, Oficyna Wolters Kluwer Business, Warsaw 2015 (in Polish).

[7] DeReń A., SKonieCZny J., A business model based on the protection of intellectual resources, Zeszyty Naukowe Uniwersytetu Szczecińskiego: Finanse, Rynki Finansowe, Ubezpieczenia, Wydawnictwo Uniwersytetu Szczecińskiego, Szczecin 2016, 1, 195-204 (in Polish).

[8] Falencikowski T., Consistency of the business model. Concept and measurement, Wydawnictwo CeDeWu, Warsaw 2013 (in Polish).

[9] HaJdasz B., Strategic choices during enterprise renewal, Stud. Oecon. Posn., 2014, 2 (11), 56-72 (in Polish).

[10] JABŁOŃSKI A., Coherence of the strategic hybrid in a network environment, Difin, Warsaw 2015 (in Polish).

[11] JABŁOŃSKI M., Business models and value creation on the capital market, Zeszyty Naukowe Uniwersytetu Szczecińskiego: Finanse, Rynki Finansowe, Ubezpieczenia, Wydawnictwo Uniwersytetu Szczecińskiego, Szczecin 2013, 60, 127-139 (in Polish).

[12] Johnson M.W., Reinvent your business model: how to seize the white space for transformation growth, Harvard Business Review Press, Boston 2018.

[13] Kavadis S., LAdos K., Loch C., Transformational business model, Harvard Business Review, April 2017, 170, 68-76.

[14] KroiK J., SKonieCZny J., The use of business models in forming corporate social responsibility, Prace Naukowe Uniwersytetu Ekonomicznego we Wrocławiu, Wrocław 2015, 387, 80-90.

[15] KRZAKIEwicz K., CYFert S., Basics of organization management, Wydawnictwo Uniwersytetu Ekonomicznego w Poznaniu, Poznań 2015 (in Polish).

[16] MALARa Z., KRoIK J., Enterprise social responsibility - constitution of concepts from a strategic perspective, Org. Kier., 2012, 1, 11-22.

[17] MALARA Z., HRYDZIUSZKo M., ZIEMBICKI P., Innovative business models as an opportunity for enterprise development [In:] I. Dudzik-Lewicka, H. Howaniec, W. Waszkielewczi (Eds.), Knowledge and information management in organization, Akademia Techniczno-Humanistyczna w Bielsku-Białej, Bielsko-Biała 2015, 9-22 (in Polish).

[18] Malara Z., Kroik J., Ziembicki P., Business model environment in segment of language schools, Raporty Wydziału Informatyki i Zarządzania Politechniki Wrocławskiej, Wrocław 2019, 3 (in Polish).

[19] MAURY A., Running lean. Iterate from plan A to a plan that works, O'Reilly, 2012.

[20] OSterwalder A., Pigneur Y., Business model generation: A handbook for visionaries, game-changers, and challengers, Wiley, Hoboken 2010.

[21] Osterwalder A., Pigneur Y., Business models creation. Visionary handbook, Helion, Gliwice 2012 (in Polish).

[22] RAPPA M., Business models on the web: Managing the digital enterprise, Am. J. Indu. Bus. Manage., 2016, 4, 28-43.

[23] SIMON H., Pricing man. How price management can change the business, ICAN Institute, Warsaw 2016 (in Polish). 
[24] Sztemberg-Lewandowska M., Factor analysis in marketing researches, Wydawnictwo Uniwersytetu Ekonomicznego we Wrocławiu, Wrocław 2008 (in Polish).

[25] Trocki M., Capital groups - creation and functioning, Wydawnictwo Naukowe PWN, Warsaw 2013 (in Polish).

[26] ZIEMBICKI P., Factors and strategy of price formation in language sector enterprises, Master Thesis, Wrocław University of Technology, Wrocław 2014 (in Polish).

[27] ZIEMBICKI P., Business models in the segment of language schools, PhD Thesis, Wrocław University of Science and Technology, Wrocław 2019 (in Polish). 